\title{
Pengaruh Latihan Resisten terhadap Kepadatan Tulang
}

\author{
Audy K. Bella, ${ }^{1}{ }^{H e d i s o n}$ Polii, ${ }^{2}$ Herlina I. S. Wungouw ${ }^{2}$
}

\author{
${ }^{1}$ Program Studi Pendidikan Dokter Fakultas Kedokteran Universitas Sam Ratulangi \\ Manado, Indonesia. \\ ${ }^{2}$ Bagian Fisiologi Fakultas Kedokteran Universitas Sam Ratulangi Manado, Indonesia \\ Email: kristabellaaudy@gmail.com
}

\begin{abstract}
Bone is a passive human locomotion. Good and strong bones must have good bone density. Bone tends to lose mass slowly when a person enters 30 years of age or it can occur earlier before a person enters old age. Bone that loses mass poses a higher risk of bone health problems such as osteopenia and osteoporosis. The decrease in bone mass can also be caused by other factors, such as a lack of physical activity. Resistance or resistance training has been recommended as a widely used treatment strategy for dealing with bone loss. Types of exercise that can be done include walking, running, weights bearing, and swimming. This study was in the form of a literature review with data searches using four databases, which are ClinicalKey, Pubmed, MedLine, and Google Scholar. Resistance exercise can increase bone density. There are two types of exercise, named aerobic and anaerobic exercises. In conclusion, anaerobic exercise is more effective in increasing bone mass density compared to aerobic exercise.
\end{abstract}

Keywords : Resistance exercise, bone density.

\begin{abstract}
Abstrak : Tulang merupakan alat gerak pasif manusia. Tulang yang baik dan kuat harus memiliki kepadatan tulang yang baik. Tulang cenderung kehilangan massa secara perlahan saat seseorang memasuki usia 30 tahun atau bisa juga terjadi lebih dini sebelun seseorang memasuki usia lanjut. Tulang yang kehilangan massanya menimbulkan risiko lebih tinggi terjadinya gangguan kesehatan tulang seperti osteopenia dan osteoporosis. Penurunan massa tulang juga dapat disebabkan oleh faktor lainnya, seperti kurangnya aktivitas fisik. Latihan tahanan atau resisten telah direkomendasikan sebagai strategi pengobatan yang banyak digunakan untuk menghadapi hilangnya massa tulang. Jenis latihan yang bisa dilakukan antara lain jalan kaki, berlari, angkat beban, dan berenang. Penelitian ini berbentuk literature review dengan pencarian data menggunakan empat database yaitu ClinicalKey, Pubmed, MedLine, dan Google Scholar. Kata kunci yang digunakan yaitu physical exercise ATAU resistance exercise ATAU resistance training ATAU effect of resistance exercise ATAU latihan tahanan ATAU latihan beban DAN bone mass ATAU bone mineral density. Latihan secara resisten dapat meningkatkan kepadatan tulang. Latihan dapat dilakukan dengan dua jenis, yaitu latihan aerobik dan anaerobik. Sebagai simpulan, latihan anaerobik lebih efektif dalam menungkatkan kepadatan massa tulang dibandingkan dengan latihan aerobik.
\end{abstract}

Kata Kunci : Latihan resisten, kepadatan tulang. 


\section{PENDAHULUAN}

Tulang merupakan alat gerak pasif manusia. Selain itu, tulang juga berperan sebagai alat penunjang tubuh, proteksi organ-organ dalam tubuh, pembentuk postur tubuh, tempat metabolisme kalsium dan mineral, dan organ hemopoetik. Tulang yang baik dan kuat harus memiliki kepadatan tulang yang baik. Massa tulang yang normal akan mempertahankan kepadatan tulang. ${ }^{1}$

Tulang merupakan organ utama penyusun tubuh yang dapat tumbuh dan berkembang, tetapi tulang cenderung kehilangan massa secara perlahan saat seseorang memasuki usia 30 tahun. $^{2}$ Tulang yang kehilangan massanya menimbulkan risiko lebih tinggi terjadinya gangguan kesehatan tulang seperti osteopenia dan osteoporosis. Gangguan tersebut juga dapat terjadi lebih dini sebelum seseorang memasuki usia lanjut, bergantung asupan nutrisi dan jenis kelamin, di mana perempuan lebih berisiko mengalami penurunan masa tulang dibandingkan lakilaki. $^{2}$

Osteoporosis dapat dijumpai di seluruh dunia dan sampai saat ini masih merupakan masalah dalam kesehatan masyarakat terutama dalam negara berkembang. Di Amerika Serikat, osteoporosis menyerang 20-25 juta penduduk, satu di antara dua sampai tiga wanita post-menopause dan lebih dari $50 \%$ penduduk di atas umur 75 80 tahun. WHO menunjukkan bahwa di seluruh dunia ada sekitar 200 juta orang yang menderita osteoporosis. ${ }^{3}$ WHO juga melaporkan bahwa $50 \%$ patah tulang adalah patah tulang paha atas yang dapat mengakibatkan kecacatan seumur hidup. ${ }^{3}$ Hasil penelitian White Paper yang dilaksanakan bersama Perhimpunan Osteoporosis Indonesia tahun 2007 melaporkan bahwa proporsi penderita osteoporosis pada penduduk yang berusia di atas 50 tahun adalah 32,3\% pada wanita dan $28,8 \%$ pada pria.

Penelitian lain yang dilakukan oleh Pusat Penelitian dan Pengembangan Gizi dan Makanan Depkes RI menunjukkan bahwa osteopenia telah menyerang pada usia muda di bawah 25 tahun dengan prevalensi $37,1 \%{ }^{4}$

Penurunan massa tulang juga dapat disebabkan oleh faktor lainnya, seperti kurangnya aktivitas fisik. Aktivitas fisik yang kurang akan menghambat aktivitas osteoblast sehingga proses pengendapan kalsium fosfat $\left(\mathrm{Ca}_{3}\left(\mathrm{PO}_{4}\right)_{2}\right)$ tulang akan berkurang. ${ }^{3,4}$ Menurut WHO pada tahun 2018, lebih dari $80 \%$ populasi orang dewasa di seluruh dunia memiliki aktivitas fisik yang kurang. ${ }^{5}$

Latihan tahanan atau resisten telah direkomendasikan sebagai strategi pengobatan yang banyak digunakan untuk menghadapi hilangnya massa tulang. Efek osteogenik dalam penambahan massa tulang dapat dirangsang dengan cara jaringan tulang harus terpapar oleh beban mekanis yang melebihi dari apa yang dialami selama aktivitas sehari-hari. Beberapa program latihan seperti latihan resistensi (Resistance Exercise (RE)) adalah latihan yang sangat bermanfaat untuk memelihara massa tulang. ${ }^{6}$

\section{METODE PENELITIAN}

Jenis penelitian ini adalah penelitian kepustakaan (library research), yaitu serangkaian penelitian yang berkenaan dengan metode pengumpulan data pustaka, atau penelitian yang objek penelitiannya digali melalui beragam informasi kepustakaan (buku, jurnal ilmiah, dan dokumen). ${ }^{7,8}$

Penentuan topik penelitian diawali dengan mermuskan suatu masalah penelitian yang berupa "Bagaimana pengaruh latihan resisten terhadap kepadatan tulang?" Data yang digunakan dalam penelitian ini berupa data sekunder, yang diperoleh bukan dari hasil pengamatan langsung melainkan diperoleh dari hasil penelitian yang telah dilakukan oleh peneliti-peneliti sebelumnya. Pencarian literature dalam literature review ini menggunakan empat database yaitu Clinical Key, PubMed, MedLine, dan Google Scholar.

Kata kunci yang digunakan dalam penelitian ini yaitu physical exercise 
ATAU resistance exercise ATAU resistance training ATAU effect of resistance exercise ATAU latihan tahanan ATAU latihan beban DAN bone mass ATAU bone mineral density. Kriteria jurnal yang akan di review berdasarkan PICOS, ${ }^{9}$ adalah responden dengan masalah kepadatan tulang yang diberikan intervensi berupa latihan fisik secara resisten. Hasil yang diharapkan yaitu responden dengan masalah kepadatan tulang yang melakukan latihan resisten akan mengalami peningkatan kepadatan tulang. Studi desain yang digunakan pada penelitian ini berupa Randomized Control Trial (RCT), Cross Sectional Survey Study, meta-analyses, ANOVA, experimental study, dan Cohort Study, yang dipublikasi dari tahun 20152020 dengan bahasa yang digunakan adalah Bahasa Indonesia dan Inggris.

Berdasarkan hasil penelusuran, peneliti mendapatkan 38 artikel menggunakan ClinicalKey, 103 artikel menggunakan PubMed, 2.007 artikel menggunakan MedLine, dan 566 artikel menggunakan Google Scholar $(\mathrm{n}=2.714)$. Hasil pencarian yang telah didapatkan kemudian dilakukan skrining berdasarkan judul yang sesuai dengan tema literature review dan didapatkan 52 artikel. Selanjutnya 52 artikel di skrining abstrak dan fulltext berdasarkan kriteria inklusi dan eksklusi didapatkan 14 artikel. Critical appraisal kepada 14 artikel studi yang memenuhi kriteria kelayakan dan yang akan digunakan dalam literature review.

\section{HASIL PENELITIAN}

Penulis melakukan pencarian menggunakan kata kunci yang sudah disusun untuk mencari artikel. Empat belas artikel full text didapatkan setelah dilakukan seleksi berdasarkan kriteria inklusi dan eksklusi. Empat belas artikel tersebut kemudian dianalisis dan dilakukan review (Tabel 3).

\section{BAHASAN}

Hasil yang diperoleh secara umum dari seluruh artikel yang telah di-review adalah terdapat kenaikan kepadatan massa tulang setelah melakukan latihan resisten

Tabel 1. Karakteristik Studi

\begin{tabular}{cl}
\hline $\begin{array}{c}\text { Tahun } \\
\text { Publikasi }\end{array}$ & \multicolumn{1}{c}{ Dari tahun 2015-2020 } \\
\hline Desain & Penelitian eksperimental dan \\
Penelitian & observasional \\
Sampling & Wanita postmenopause yang \\
Penelitian & menderita osteoporosis, pria \\
& yang memiliki kepadatan \\
& massa tulang yang rendah, \\
& mahasiswa prodi keperawatan \\
& angkatan 2019, wanita yang \\
& mengikuti zumba, wanita \\
& penderita kanker, wanita \\
& muda yang memiliki \\
& kepadatan massa tulang yang \\
& rendah, dan pasien yang \\
& menderita DM tipe 2 \\
Secara umum dari ke-14 \\
artikel di atas, pengukuran \\
massa tulang diukur dengan \\
Denelitian \\
DXA (Dual-energy X-ray \\
Absorptiometri).
\end{tabular}

Tabel 2. Karakteristik Subjek

\begin{tabular}{ll}
\hline Total subjek & Laki-laki: 127 responden \\
penelitian & $\begin{array}{l}\text { dengan usia rerata 48 } \\
\text { tahun }\end{array}$ \\
& $\begin{array}{l}\text { Perempuan: 939 } \\
\text { responden dengan usia } \\
\text { rerata 41 tahun }\end{array}$ \\
& Pasien penderita DM \\
& Tipe 2: 200 responden \\
\hline Range umur & Kisaran usia rerata dari \\
secara & ke-14 artikel adalah 22- \\
keseluruhan & 55 tahun \\
\hline
\end{tabular}

\section{Latihan resisten pada wanita post- menopause}

Jenis latihan resistensi yang dianjurkan bagi wanita postmenopause adalah latihan anaerobik seperti berjalan kaki, lari, dan angkat beban. Latihan resisten ini dianjurkan dilakukan minimal sebanyak dua kali per minggu dengan lima set dan lima repetisi. Latihan resisten ini meliputi pemanasan selama 10 menit, latihan 


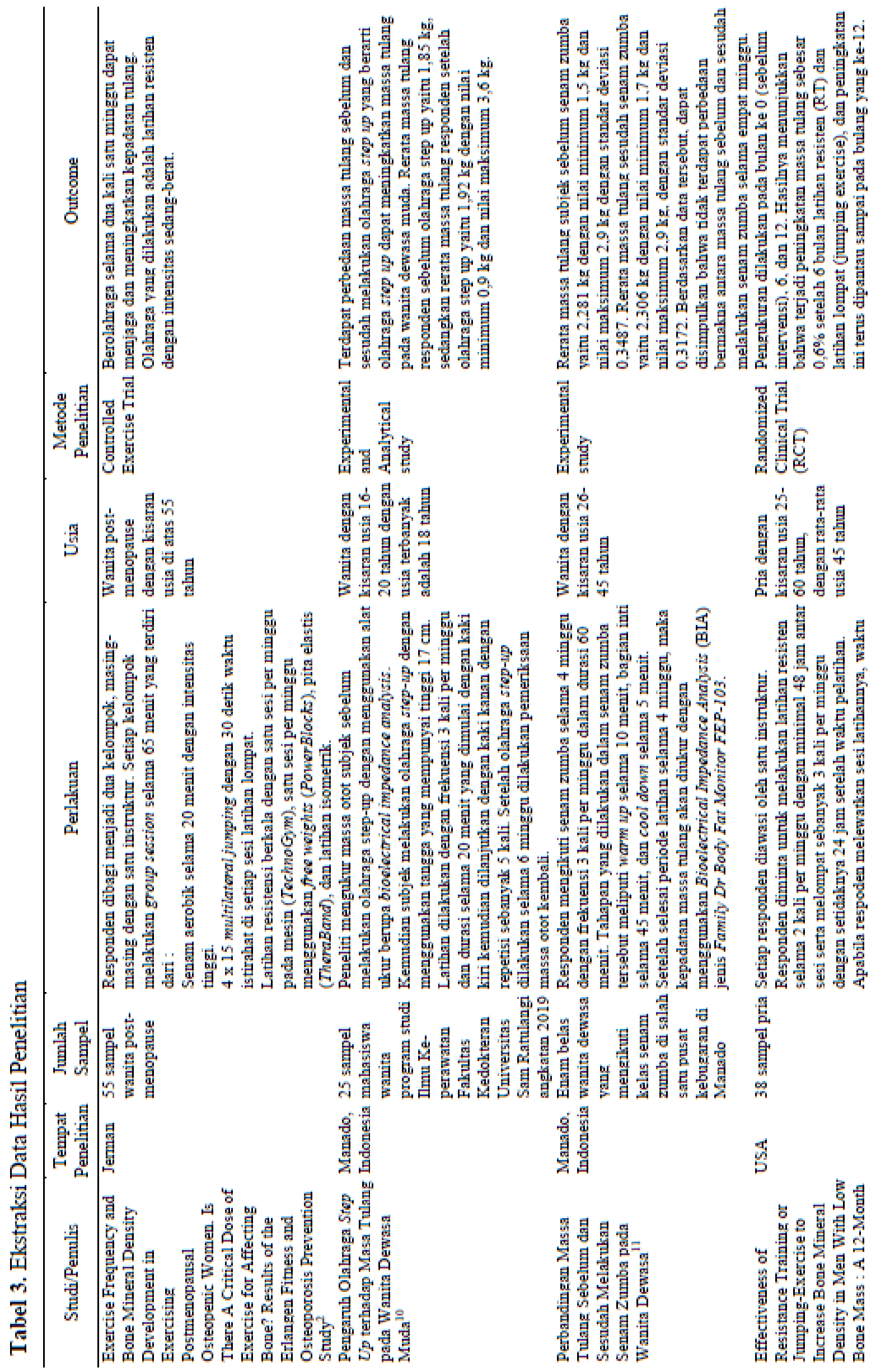




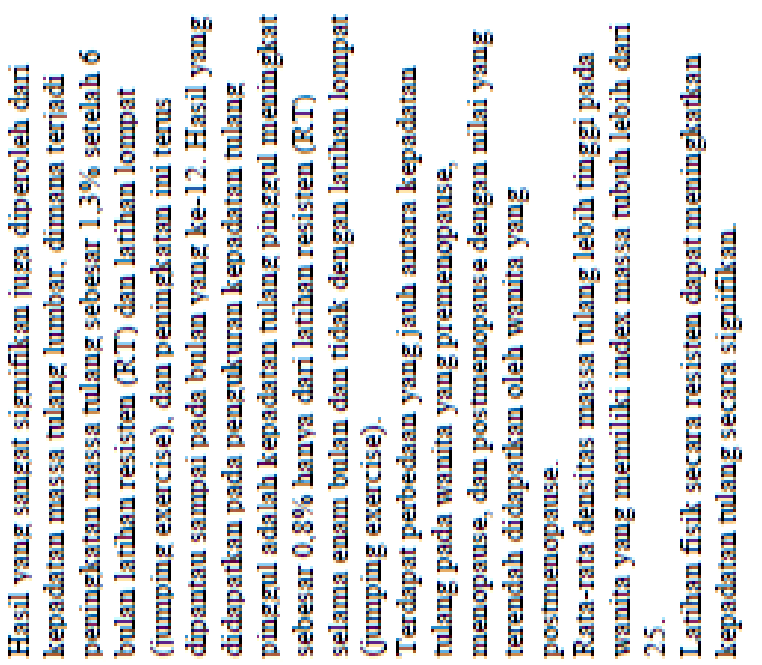

혈

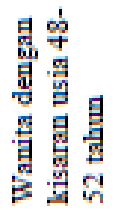

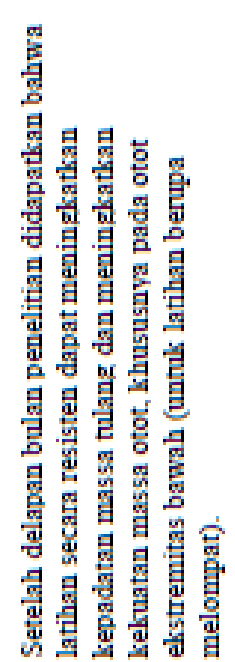

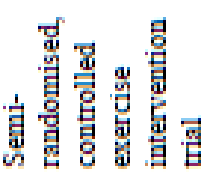

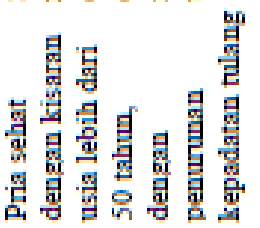

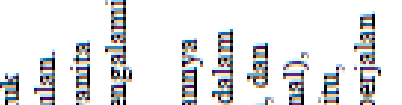

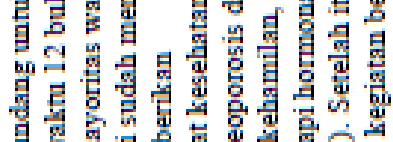

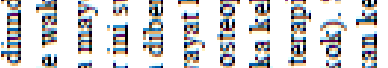

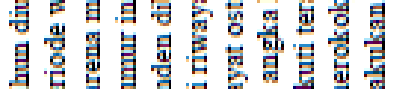

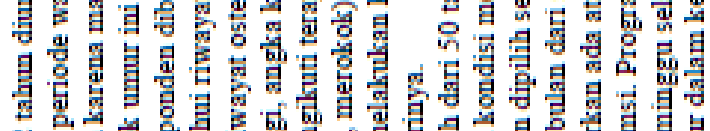

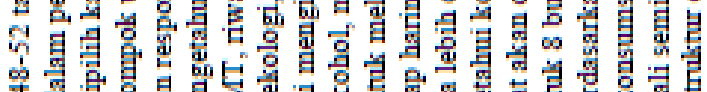

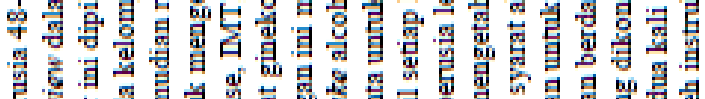

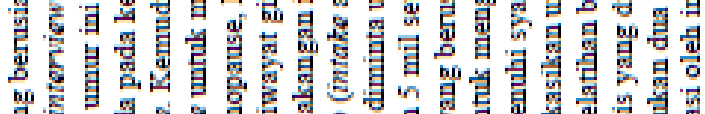

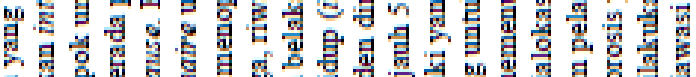

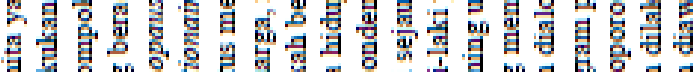

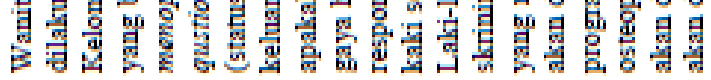

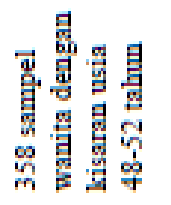

藏

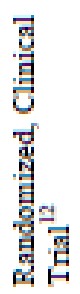

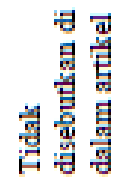

费

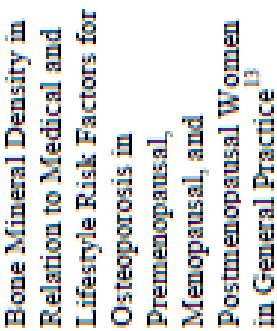

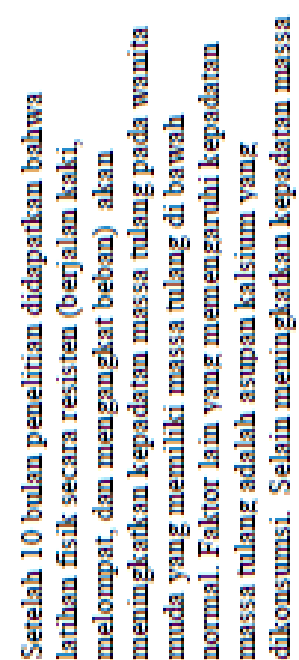

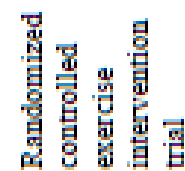

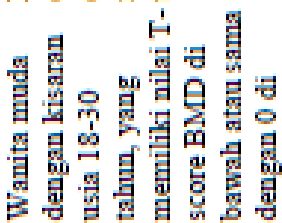

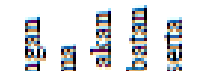

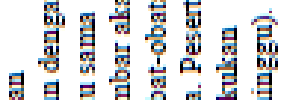

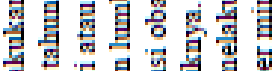
두의.

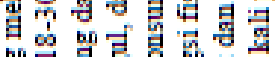
耀

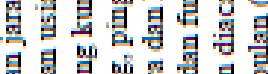

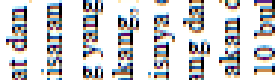

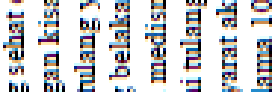

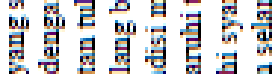

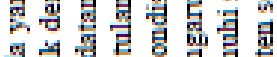

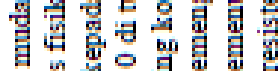

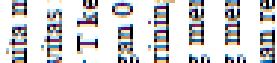

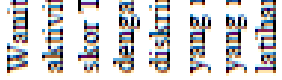

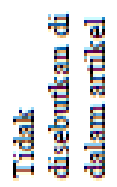

$$
\begin{aligned}
& \text { 量 }
\end{aligned}
$$

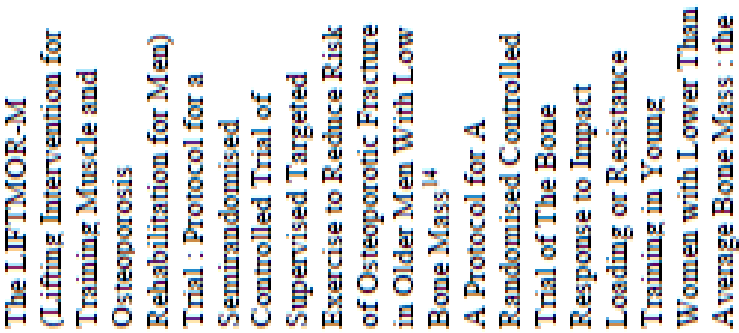




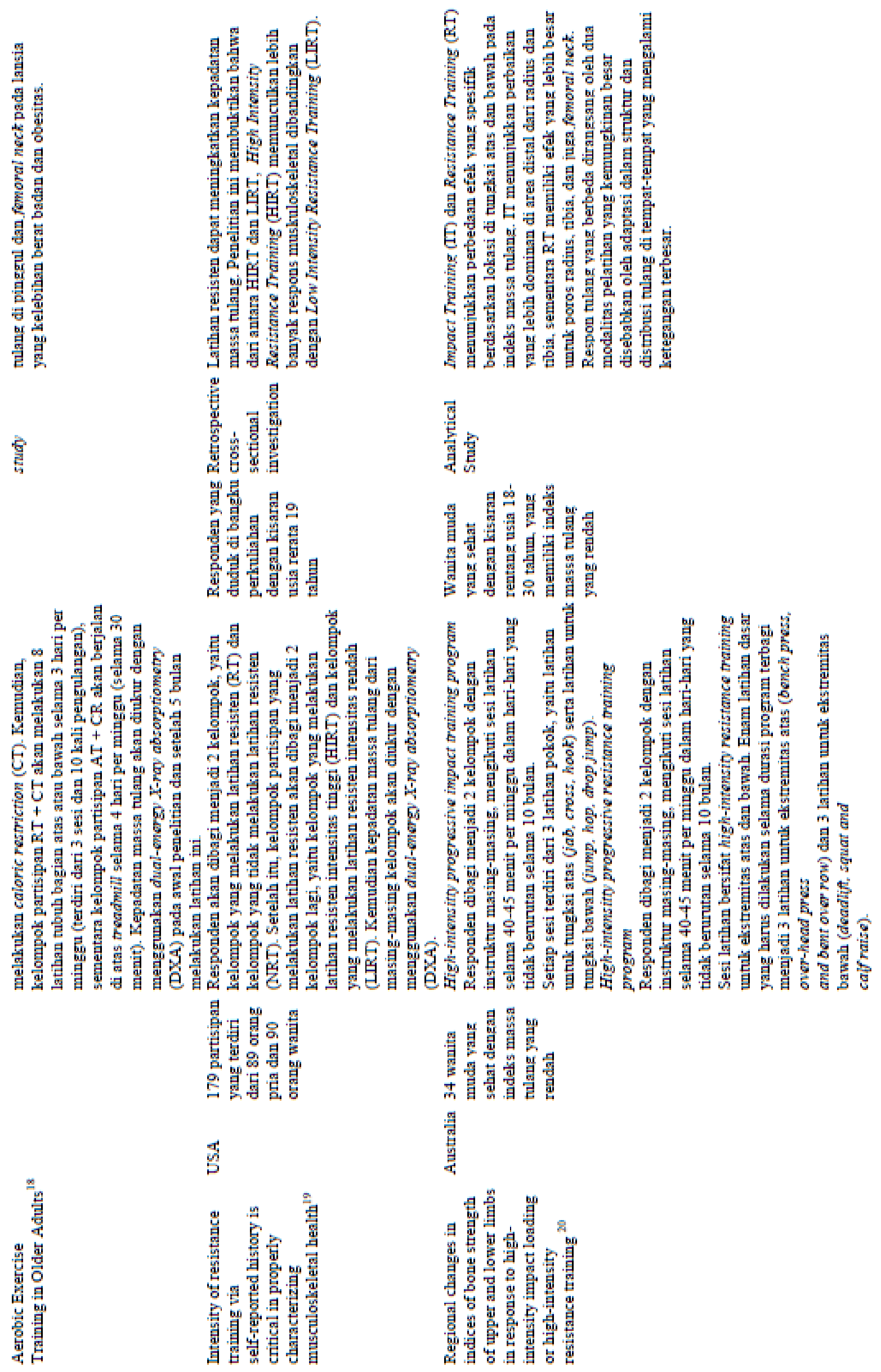



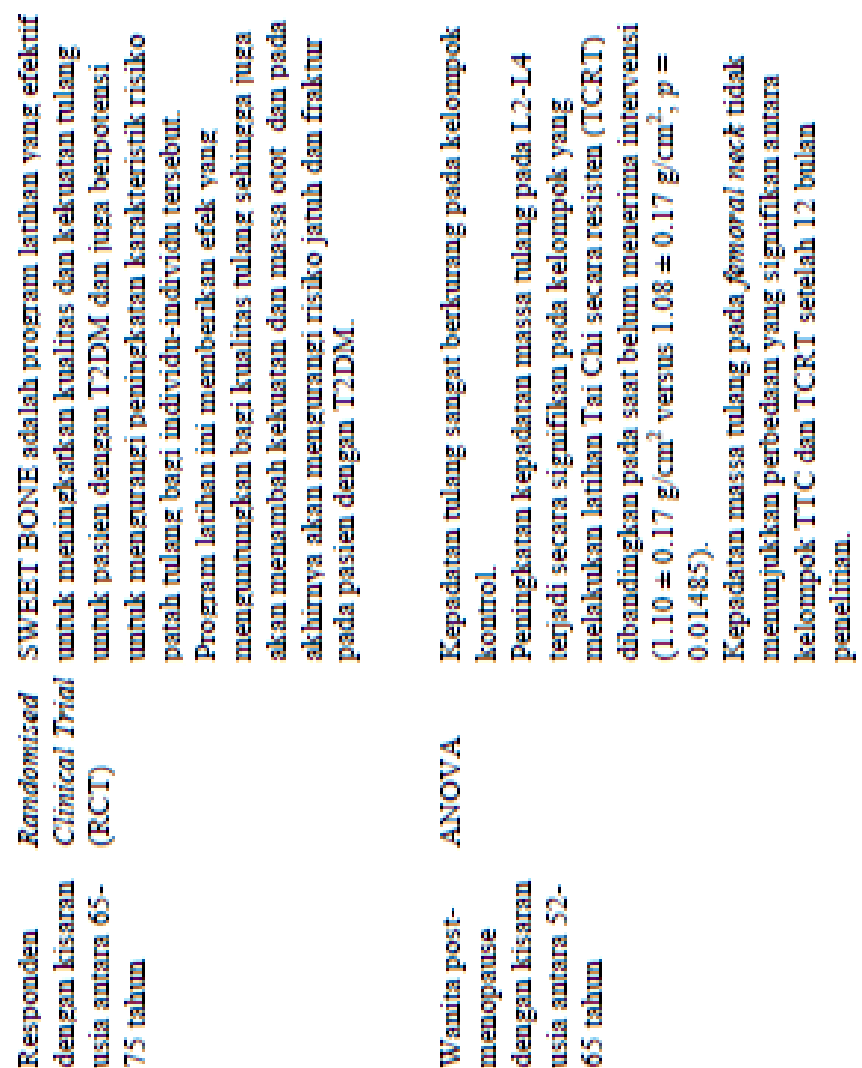

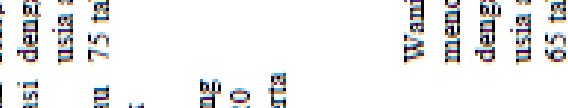

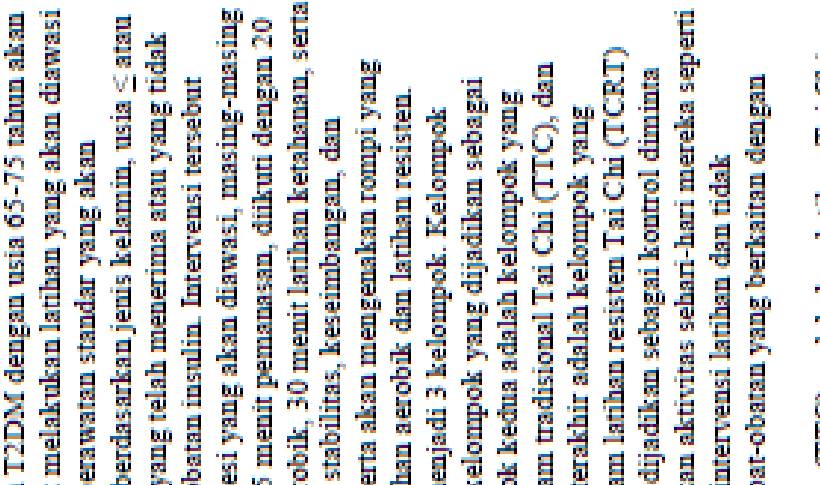

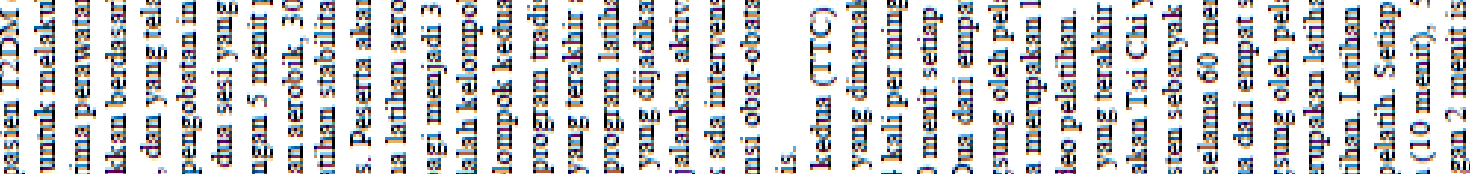

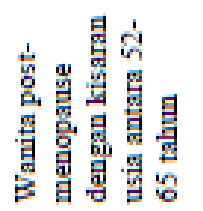

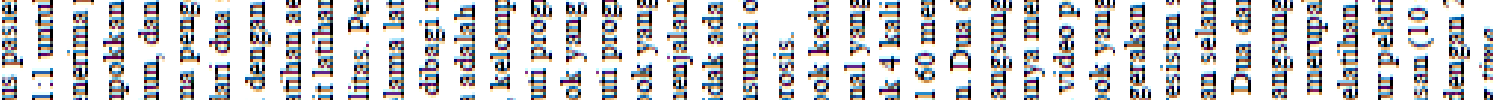

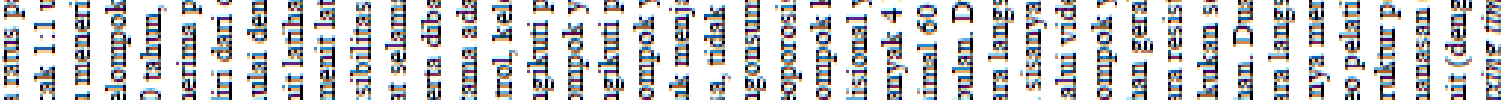

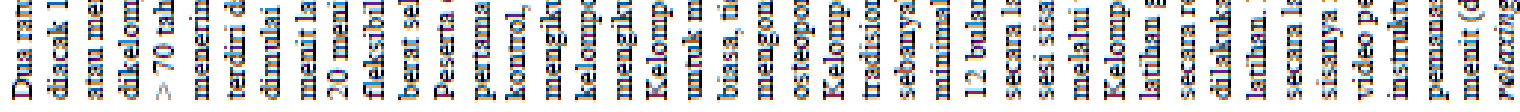

娄育

䁘

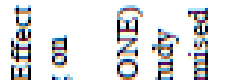

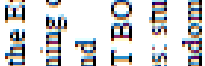

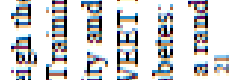

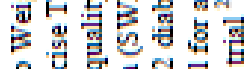

o

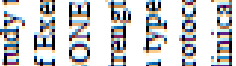

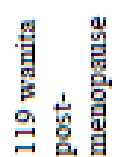

蒠

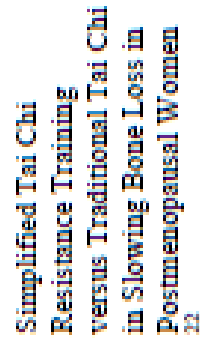

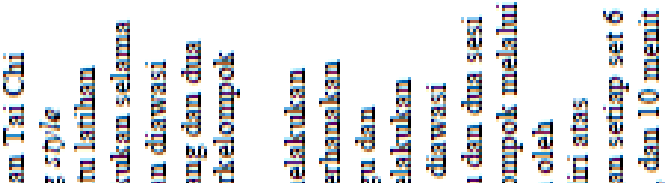

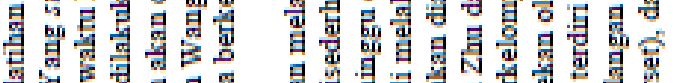

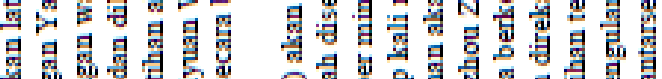

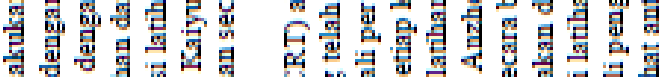

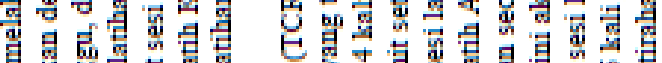

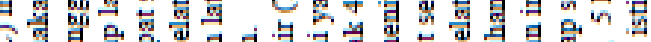

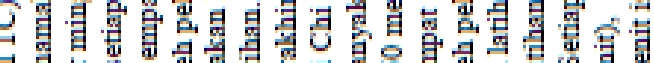

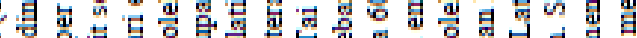


dengan lima set dan lima repetisi (dengan dua menit waktu istirahat antarset), dan 10 menit gerakan relaksasi. Latihan resisten ini terbukti dapat meningkatkan kepadatan tulang wanita postmenopause sebanyak $0,17 \mathrm{~g} / \mathrm{cm}^{2}$ pada tulang belakang, pinggul, dan femoral neck.

\section{Latihan resisten pada pasien Diabetes Melitus (DM) Tipe 2}

Jenis latihan resisten yang dapat dilakukan pada pasien dengan diabetes melitus tipe 2 ini adalah latihan angkat beban. Latihan ini dimulai dengan lima menit pemanasan, diikuti dengan 20 menit latihan aerobik, 30 menit latihan ketahanan, serta 20 menit latihan stabilitas, keseimbangan, dan fleksibilitas, kemudian di akhiri dengan lima menit gerakan relaksasi. Latihan resisten ini dianjurkan dilakukan minimal 2 kali per minggu. Latihan resisten yang dilakukan oleh penderita DM tipe 2 terbukti dapat meningkatkan kepadatan massa tulang.

\section{Perbandingan jenis olahraga step up dengan senam zumba}

Hasil penelitian yang diperoleh dari tabel ekstraksi data menjelaskan bahwa dari jenis olahraga antara step up dan senam zumba, terbukti bahwa olahraga step up lebih memberikan efek yang signifikan terhadap kepadatan tulang. Hal ini disebabkan karena olahraga step up memberikan beban mekanik pada tulang sehingga tulang akan "dipaksa" untuk melakukan proses remodeling tulang. Hal ini berbeda dengan olahraga senam zumba. Olahraga senam zumba dinilai tidak memberikan beban mekanik pada tulang seperti olahraga step up sehingga peningkatan kepadatan massa tulang yang terjadi tidak terlalu bermakna. ${ }^{10,11}$

\section{SIMPULAN}

Jumlah responden yang lebih banyak mengalami penurunan massa tulang berasal dari golongan lansia ( $\geq 50$ tahun). Jumlah responden yang mengalami penurunan massa tulang ditemukan lebih banyak pada wanita dibandingkan pria. Aktivitas fisik yang dilakukan secara rutin dan teratur terbukti dapat meningkatkan kepadatan massa tulang. Aktivitas fisik yang dilakukan secara rutin dan teratur dapat menjaga kesehatan tulang dan mencegah mengalami penurunan kepadatan tulang secara dini. Aktivitas fisik yang memiliki efek lebih baik untuk meningkatkan kepadatan massa tulang adalah aktivitas fisik anaerobik seperti melompat, berlari, dan mengangkat beban. Kelompok lansia yang mengalami osteoporosis yang diberikan intervensi berupa latihan fisik secara resisten terbukti mengalami peningkatan kepadatan massa tulang. Latihan fisik yang dilakukan secara resisten diperkirakan dapat meningkatkan kepadatan massa tulang pada responden yang menderita diabetes mellitus (DM) tipe dua.

\section{Konflik Kepentingan}

Penulis menyatakan tidak terdapat konflik kepentingan dalam studi ini.

\section{DAFTAR PUSTAKA}

1. Sherwood L. Fisiologi Manusia: Dari Sel ke Sistem. Vol. 6. Jakarta: EGC, 2011.

2. Kemmler W, von Stengel S, Kohl M. Exercise frequency and bone mineral density development in exercising postmenopausal osteopenic women. Is there a critical dose of exercise for affecting bone? Results of the Erlangen Fitness and Osteoporosis Prevention Study. Bone 2016;89: $1-6$.

3. Kementrian Kesehatan RI. Infodatin Osteoporosis Pdf. 2015. p. 1-3.

4. Wuryanto MA, Peminatan M, Tropik P, Undip FKM. Gambaran Densitas Mineral Tulang (Dmt) Pada Kelompok Dewasa Awal (19-25 Tahun) (Studi Di Fakultas Kesehatan Masyarakat Universitas Diponegoro). J Kesehat Masy. 2017;5(4):424-30. 
5. World Health Organization. SeventyFirst World Health Assembly A71/18 Provisional agenda item 12.2 Physical activity for health More active people for a healthier world: draft global action plan on physical activity 2018-2030 Report by the Director-General. 2018;2014(February):1-8.

Available from: http://apps.who. int/iris/bitstream/10665/148114/1/ 9789241564854_eng.pdf,accessed 23February2018

6. Sibonga J, Matsumoto T, Jones J, Shapiro J, Lang T, Shackelford L, et al. Resistive exercise in astronauts on prolonged spaceflights provides partial protection against spaceflightinduced bone loss. Bone 2019;128:112037.

7. Hinton PS, Nigh P, Thyfault J. Effectiveness of resistance training or jumping-exercise to increase bone mineral density in men with low bone mass: A 12-month randomized, clinical trial. Bone 2015;79:203-12.

8. McKnight A, Steele K, Mills K, Gilchrist $\mathrm{C}$, Taggart $\mathrm{H}$. Bone mineral density in relation to medical and lifestyle risk factors for osteoporosis in premenopausal, menopausal and postmenopausal women in general practice. $\mathrm{Br} \mathrm{J}$ Gen Pract. 1995;45(395):317-20.

9. Melfianora. Penulisan Karya Tulis Ilmiah Dengan Studi Literatur. Open Sci Framew 2019;1-3. Available from: osf.io/efmc2

10. Triandini E, Jayanatha S, Indrawan A, Werla Putra G, Iswara B. Metode Systematic Literature Review untuk Identifikasi Platform dan Metode Pengembangan Sistem Informasi di Indonesia. Indones J Inf Syst. 2019;1(2):63.

11. Nursalam H. Penulisan Literature Review dan Systematic Review Pada Pendidikan Kesehatan (Contoh). Priyantini D, ed.
Surabaya: Fakultas Keperawatan Universitas Airlangga, 2020.

12. Rungkat TA, Lintong F, Moningka MEW. Pengaruh Olahraga Step-up Terhadap Massa Otot Pada Wanita Dewasa Muda. eBiomedik. 2020; 8(1):54-60.

13. Senduk MNW, Polii H, Doda DVD. Perbandingan Massa Tulang Sebelum dan Sesudah Melakukan Senam Zumba pada Wanita Dewasa. Jurnal Biomedik 2019; 11(1): 17-22.

14. Harding AT, Weeks BK, Watson SL, Beck BR. The LIFTMOR-M (Lifting Intervention for Training Muscle and Osteoporosis Rehabilitation for Men) trial: Protocol for a semirandomised controlled trial of supervised targeted exercise to reduce risk of osteoporotic fracture in older men with low bone mass. BMJ Open. 2017;7(6):e014951.

15. Lambert C, Beck BR, Harding AT, Watson SL, Weeks BK. A protocol for a randomised controlled trial of the bone response to impact loading or resistance training in young women with lower than average bone mass: The OPTIMA-Ex trial. BMJ Open 2017;7(9):e016983:112.

16. Watson SL, Weeks BK, Weis LJ, Harding AT, Horan SA, Beck BR. High-Intensity Resistance and Impact Training Improves Bone Mineral Density and Physical Function in Postmenopausal Women With Osteopenia and Osteoporosis: The LIFTMOR Randomized Controlled Trial. J Bone Miner Res 2018;33(2):21120.

17. Almstedt HC, Grote S, Korte JR, Perez Beaudion S, Shoepe TC, Strand S, et al. Combined aerobic and resistance training improves bone health of female cancer survivors. Bone Reports 2016;5:274-9. 
18. Beavers KM, Beavers DP, Martin SB, Marsh AP, Lyles MF, Lenchik L, et al. Change in Bone Mineral Density during Weight Loss with Resistance Versus Aerobic Exercise Training in Older Adults. Journals Gerontol - Ser A Biol Sci Med Sci 2017;72(11):1582-5.

19. Shoepe TC, LaBrie JW, Mello GT, Leggett AG, Almstedt HC. Intensity of resistance training via self-reported history is critical in properly characterizing musculoskeletal health. BMC Musculoskelet Disord. 2020;21(1):1-14.

20. Lambert C, Beck BR, Harding AT, Watson SL, Weeks BK. Regional changes in indices of bone strength of upper and lower limbs in response to high-intensity impact loading or high-intensity resistance training. Bone 2020; 132:115192.

21. Balducci S, Conti F, Sacchetti M, Russo $\mathrm{CR}$, Argento G, Haxhi J, et al. Study to Weigh the Effect of Exercise Training on BONE quality and strength (SWEET BONE) in type 2 diabetes: study protocol for a randomised clinical trial. BMJ Open 2019;9(11): e027429:1-11.

22. Wang H, Yu B, Chen W, Lu Y, Yu D. Simplified Tai Chi resistance training versus traditional Tai Chi in slowing bone loss in postmenopausal women. Evid Based Complement Alternat Med 2015; 2015:379451:1-7 